\title{
Ethics board members quit over 'imbalance'
}

Munich. The biologist and Nobel prizewinner Rita Levi-Montalcini last week resigned as a member (and honorary president) of Italy's national bioethics committee, in protest at a decision by the former prime minister Silvio Berlusconi to appoint nine new committee members, all of whom are orthodox Roman Catholics.

Two other members, including the committee's vice president, have also resigned. The nine appointments create a strong Catholic majority to the committee - - and have been widely condemned as an act of political manipulation.

The national bioethics committee was established in 1990 as an advisory group to the government, in line with similar committees in other European countries. Its 40 members are appointed by the prime minister, and its composition is intended to represent a balance of the different views on bioethics that prevail in Italy.

Berlusconi, the leader of the Forza Italia party, upset this balance when he signed a decree on 16 December, during the last days of his government, nominating the new Catholic members. The decree also gives the committee a four-year term of office, in contrast to its previous two-year terms.

Berlusconi hopes to be asked to form a new coalition government and his creation of a majority of orthodox Catholics on the bioethics committee is widely seen as an attempt to woo potential new coalition partners by appealing to the Roman Catholic Church and thus the Partito Popolare Italiano (PPI) party. The PPI is the successor to the disgraced Christian Democrats. It is not at present represented in government, but could be if new elections are called.

The move is also being seen as an attempt to appease Forza Italia's main coalition partners, the right-wing Alleanza Nazionale. This wants to change Italy's abortion laws, which permit abortion in certain circumstances.

Such political manipulation makes nonsense of the committee's attempts to represent a balance of views, says its former vice-president, Giovanni Berlinguer, professor of public health at the First University of Rome's faculty of science. Berlinguer announced his resignation last week, at the same time as Levi-Montalcini and a second committee member, Eugenio Lecaldano. "Some of the most prominent scientists and philosophers were removed from the committee to make way for new members from the very dogmatic, orthodox Catholic faction", he says.

One scientist who has been dropped from the committee is molecular biologist Glauco Tocchini-Valentini, who first learnt about his dismissal in the newspapers several days before he received his official letter from Berlusconi.

The resignation of Levi-Montalcini has provoked particular concern among Italian scientists. Berlinguer hopes that the resulting publicity will force the next prime minister to return the committee to "a more sensible balance", and says that in such circumstances he would be prepared to withdraw his resignation.

But Levi-Montalcini is not likely to return. She is keen that her resignation should not seen as anti-Catholic. "I resigned because the balance of the committee had been changed; I would also have resigned if the balance had been changed in the other direction," she says.

But she is also unhappy with the work of the committee, saying that it has moved too slowly and keeps repeating themes - such as the ethics of in vitro fertilization - that have already been dealt with and legislated for in the United Kingdom and France, without drawing conclusions.

Berlinguer agrees that the work had been slow, but says that the dialogue has always been good. He adds that "in order to influence, it is necessary that the legislative powers are ready to be influenced. But bioethics has never been of great concern to the Italian government."

Alison Abbott

\section{'Out-dated figures misled critics of space station'}

Washington. The National Aeronautics and Space Administration (NASA) has hit back at the report of a government watchdog agency which said that it will lack sufficient scientists on the ground to support the research it is planning to carry out on the space station.

The space agency says it has already started to support most of the microgravity and life sciences investigators that the General Accounting Office (GAO) has claimed it will not have in place when space station research starts in 1998.

The GAO report, Space Station: Plans to Expand Research Community Do Not Match Available Resources, says that NASA will need to increase the number of groundbased microgravity researchers it supports from 73 in 1992 to 240 by 1998 , and concludes that this cannot be done within planned funding levels.

Opponents of the space station led by Senator Bill Cohen (Republican, Maine), who requested the report, jumped on its central conclusion when it was released late last month. "With its research budget frozen, NASA will not be able to maintain its current number of scientists, much less triple their number as the space station re- quires," Cohen said.

But Arnauld Nicogossian, a deputy administrator of NASA's office of life and microgravity science, says his office had already built up strength since 1992 to the point where it is funding 209 ground-based microgravity investigators. "The GAO used the old data," he says. "I don't know why".

Frank Degnan of the GAO, the investigative arm of Congress, says that NASA officials - including Nicogossian - reviewed the draft report at a meeting in October, and should have raised any problems then. "No-one indicated that the number had grown to 209 ," he said. "If they weren't aware of it then, they should have been."

But NASA officials say the GAO threw so much information at them during the October meeting that they overlooked some figures that were correct, but incomplete. Only later did the figures became a focal point of the report.

Bob Rhome, director of NASA's microgravity science and applications divi- sion, says that while the data in the GAO report are technically correct, their interpretation was wrong. Rhome says that NASA has been able to build up microgravity

IMAGE
UNAVAILABLE
FOR COPYRIGHT
REASONS

The space station will need considerable back-up from ground-based research teams.

research quickly over the past two years by diverting resources from the space station's research and development budget - and has informed Congress of what it is doing. "The fact is that we've got four more years to find 31 extra investigators," says Rhome. Colin Macilwain 